\title{
A Decision Support Tool for Sustainable Supplier Selection in Manufacturing Firms
}

\author{
Ifeyinwa Juliet Orji, Sun Wei \\ Dalian University of Technology (China) \\ ifyorji09@yahoo.com,sunwei@,dlut.edu.cn
}

Received: July 2014

Accepted: November 2014

\section{Abstract:}

Purpose: Most original equipment manufacturers (OEMs) are strategically involved in supplier base rationalization and increased consciousness of sustainable development. This reinforces need for accurately considering sustainability in supplier selection to improve organizational performance. In real industrial case, problems are unavoidable and pose huge challenge to accurately incorporate sustainability factors into supplier selection. Such problems include imprecise data, ambiguity of human judgment, uncertainty among sustainability factors and the need to capture all subjective and objective criteria

Design/methodology/approach: This study develops a model based on integrated multicriteria decision making ( $\mathrm{MCDM}$ ) methods to solve such problems. The developed model applies Fuzzy logic, DEMATEL and TOPSIS to effectively analyze the interdependencies between sustainability criteria and to select the best sustainable supplier in fuzzy environment while capturing all subjective and objective criteria. A case study is illustrated to test the proposed model in a gear manufacturing company, an OEM to provide insights and for practical applications.

Findings: Results show that social factors of sustainability ranks as the most important in sustainable supplier selection. RFP ranks as the most important sub- criterion with score of 3 . 7442. Also, the highest net causers are WS and quality with scores of 1.2818 and 0.3409 
respectively. This implies that during sustainable supplier selection, it is suggested that emphasis should be placed on work safety and quality of the respective suppliers. $A_{6}$ is identified as the best possible sustainable supplier with a relative closeness to the ideal solution $L_{i}$ of 0.527 . This is as a result of $A_{6}$ being closest to the positive ideal solution and farthest from the negativeideal solution during implementing sustainable supplier selection in the case study.

Originality/value: The model is capable of capturing all subjective and objective criteria in fuzzy environment to accurately incorporate sustainability factors in supplier selection. Work safety and quality necessitates the most emphasis during implementing sustainable supplier selection because they highly influence all other sub- criteria.

Keywords: supplier selection, sustainability, Original Equipment Manufacturers (OEM)

\section{Introduction}

Globally, manufacturing firms compete in a complex and rapidly changing environment. Currently, the supply market of the gear manufacturing company as an original equipment manufacturer (OEM) is shifting from one sector to another (Radke, 2008). Industries consider how to manage supply chain operations more efficiently to improve organizational performance. Supplier selection is a crucial supply chain operation having great impact on integration of the supply chain relationship and able to enhance organizational performance. Original equipment manufacturers (OEMs) are strategically involved in supplier base rationalization and increased consciousness of sustainable development. This reinforces the need to embed sustainability factors into supplier selection. Sustainability is an emerging trend that has been incorporated in agriculture, manufacturing and business development. Sustainability is also an emerging issue linked with supplier selection (Upadhyay, 2012). Globally, companies are increasingly acknowledging the importance of incorporating sustainability factors in supplier selection. There still exists a necessity to incorporate sustainability factors such as respect for policy and employee health in supplier selection problems (Bai \& Sarkis, 2009). In particular, a challenge remains to ensure that sustainability considerations are embedded within all sourcing processes of original equipment manufacturers (OEMs).

Sustainable supplier selection involves analyzing interdependencies between sustainability criteria relevant to supplier selection and determining supplier performance with respect to the criteria. However, imprecise data, ambiguity of human judgment and uncertainty among sustainability factors are unavoidable and pose huge challenge to accurately implement sustainable supplier selection in an OEM. Also, it is necessary to consider conflicting subjective and objective factors during implementing sustainable supplier selection in an OEM. In efforts 
towards implementing sustainable supplier selection in real industrial case, researchers have started to employ multi- criteria decision making (MCDM) method for supplier selection in fuzzy environment (Bottani \& Rizzi, 2008; Chen, 2009; Awasthi, Chauhan \& Goyal, 2010; Amindoust, Ahmed, Saghafinia \& Bahreininejad, 2012). Their works applied fuzzy logic to solve the challenges of imprecise data and ambiguous human judgment. However, no literature exists on model capable of capturing all subjective and objective criteria in fuzzy environment to accurately implement sustainable supplier selection. Hence, a novel model based on integrated multi-criteria decision making (MCDM) methods is developed in this study. The model is capable of capturing all objective and subjective criteria in other to accurately implement sustainable supplier selection in fuzzy environment. DEMATEL is a preferred decision making technique because it can pragmatically visualize complicated casual relationship among factors. To handle imprecise input data and ambiguous human judgments, fuzzy logic is preferred. Thus, the developed novel model employs DEMATEL (Wu \& Lee, 2007) and fuzzy logic (Chang, Chang \& Wu, 2011) to find the mutual relationships and strengths of interdependencies within sustainability factors relevant to supplier selection in fuzzy environment. Also, TOPSIS (Bhutia \& Phipon, 2012) most preferred for capturing all objective and subjective criteria is applied in this work to choose the best possible sustainable supplier. The objectives of study are three- folds:

(a) to investigate the present supplier selection structure in a gear manufacturing company and to deduct the relevant sustainability sub- criteria therein, (b) to develop a novel model based on multi- criteria decision making (MCDM) methods to accurately implement sustainable supplier selection and (c) to apply the developed model to analyze interdependencies among sustainability criteria relevant to supplier selection and choose the best sustainable supplier in the named case study.

It is thus expected that the result of this work will help decision makers to effectively analyze the interdependencies between relevant subjective and objective criteria and to select the best possible sustainable supplier in fuzzy environment in other to improve organizational performance.

\section{Literature Review}

Traditional methods of supplier selection consider only economic aspects. They cannot meet the requirements of businesses in today's competitive environment, hence social and environmental aspects should also be included in supplier selection to improve organization performance. Even though many publications exist on supplier selection, the research on supplier selection with sustainability considerations is not adequate (Amindoust et al., 2012). The sustainability attributes relevant for supplier selection as obtained from the literature are summarized in Table 1. Multi-criteria decision making methods, such as analytic hierarchy 
process (AHP), analytic network process (ANP), data envelopment analysis (DEA), DEMATEL, TOPSIS and mathematical programming have been applied to supplier selection problems $\mathrm{Wu}$ \& Oslon, 2008; Kheljani, Ghodsypour \& Brien, 2009; Lin, Chen \& Ting, 2011). AHP has being applied to vendor selection (Wang, Huang \& Dismukes, 2004; Kumar \& Roy, 2010). The supplier selection problem was structured as an integrated lexicographic goal programming and AHP model including both quantitative and qualitative conflicting factors (Cebi \& Bayraktar, 2003). AHP Approach was applied for Supplier Evaluation and Selection in a Pharmaceutical Manufacturing Firm in Ghana (Asamoah, Annan \& Nyarko, 2012). A study which applied TOPSIS and fuzzy multi-objective model integration was proposed for supplier selection problem (Jadidi, Hong, Firouzi, Yusuff \& Zulkifli, 2008). An integrated analytic hierarchy process (AHP) and preemptive goal programming (PGP) was suggested for the supplier selection problem (Wang et al., 2004). Multi Choice Goal Programming (MCGP) was proposed for supplier selection (Chang, 2007). Most of the above stated approaches did not consider all subjective and objective factors relevant for implementing sustainable supplier selection. Also, the approaches did not solve challenges of data imprecision and ambiguous human judgment.

To solve the problems of imprecise data and ambiguous human judgments in supplier selection, fuzzy theory is most preferred (Chang et al., 2011). Bottani and Rizzi (2008) integrated fuzzy with cluster analysis and MCDM to solve the supplier selection problem. Awasthi et al. (2010) in their work integrated fuzzy with TOPSIS to evaluate environmental performances of suppliers. However, their approaches did not consider all sustainability factors relevant to sustainable supplier selection; they did not consider social aspects of sustainability.

Amindoust et al. (2012) in their work proposed Fuzzy inference system for implementing sustainable supplier selection. Their work solved the problems of imprecise data and ambiguous human judgments. It also solved the problem of uncertainty amongst sustainability criteria by employing DEMATEL. However, it did not effectively capture all the subjective and objective factors relevant to sustainable supplier selection.

DEMATEL is most preferred to find the mutual relationships of interdependencies and strength of interdependence within sustainability factors (Wu \& Lee, 2007). DEMATEL approach is considered as one of the best tools for dealing with the importance and casual relationships among the evaluation criteria (Chiu, Chen, Shyu \& Tzeng, 2006; Liou, Tzeng \& Chang, 2007; Tzeng, Chiang \& Li, 2007; Wu \& Lee, 2007; Lin et al., 2009). One of the major advantages of DEMATEL method is that it can confirm interdependence among variables and aid in the development of a directed graph to reflect the interrelationships between variables. DEMATEL is useful for visualizing the structure of complicated causal relationships with matrices or digraphs. Hence, the DEMATEL model can convert the relationship between the causes and effects of criteria into an intelligible structural model of the system. It is able to verify interdependence among the unpredictable features or attributes thus revealing the 
characteristic trend and reflects the interrelationship between variables by improving the directed graph (Hori \& Shimizu, 1999; Tamura, Nagata \& Akazawa, 2002).

\begin{tabular}{|c|c|c|c|c|c|c|c|c|c|c|c|c|c|}
\hline \multirow[t]{2}{*}{ Criteria/Sub- criteria } & \multicolumn{13}{|c|}{ References } \\
\hline & 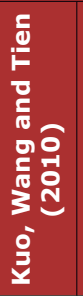 & 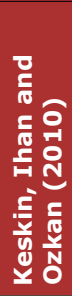 & 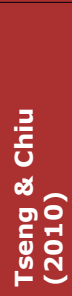 & 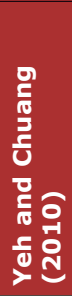 & 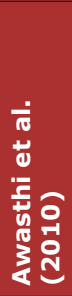 & 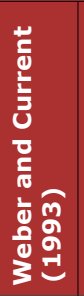 & 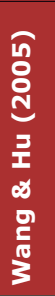 & 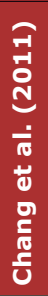 & 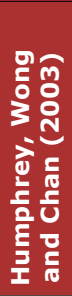 & 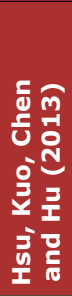 & 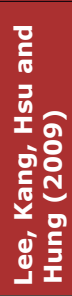 & 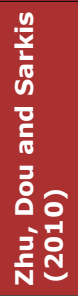 & 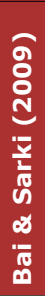 \\
\hline \multicolumn{14}{|l|}{ Economic } \\
\hline Price & $\checkmark$ & $\checkmark$ & & $\checkmark$ & & & $\checkmark$ & & & & & $\checkmark$ & \\
\hline On time delivery & $\checkmark$ & & $\checkmark$ & $\checkmark$ & & & $\checkmark$ & & & & & $\checkmark$ & \\
\hline Service \& Relationship & $\checkmark$ & & $\checkmark$ & & & $\checkmark$ & $\checkmark$ & $\checkmark$ & & & & $\checkmark$ & \\
\hline Flexibility & & & $\checkmark$ & & & & & & & & & $\checkmark$ & \\
\hline Quality & $\checkmark$ & & $\checkmark$ & & & & $\checkmark$ & $\checkmark$ & & & $\checkmark$ & $\checkmark$ & \\
\hline Financial ability & & $\checkmark$ & & & & & & & & & & & \\
\hline Production facilities & & $\checkmark$ & & & & & & & & & & & \\
\hline Organization & & & $\checkmark$ & & & & & & & & & $\checkmark$ & \\
\hline \multicolumn{14}{|l|}{ Social } \\
\hline Rights of stakeholders & $\checkmark$ & & & & & & & & & & & & \\
\hline Work safety & & $\checkmark$ & & & & & & & & & & & \\
\hline Information disclosure & $\checkmark$ & & & & & & & & & & & & \\
\hline Respect for policy & $\checkmark$ & & & & & & & & & & & & \\
\hline \multicolumn{14}{|l|}{ Environmental } \\
\hline Green supply chain management & & & $\checkmark$ & $\checkmark$ & & & & & & & & & \\
\hline Recycling & & & & $\checkmark$ & & & & & & & & & \\
\hline Waste electrical equipments & $\checkmark$ & & & & & & & & & & & & \\
\hline Ozone depleting chemicals & $\checkmark$ & & & & & & & & & & & & \\
\hline Green R \& D & & & $\checkmark$ & & $\checkmark$ & & & & & & & & \\
\hline Green design & & & $\checkmark$ & $\checkmark$ & $\checkmark$ & & & & $\checkmark$ & & & & \\
\hline Environmental management system & $\checkmark$ & & $\checkmark$ & $\checkmark$ & $\checkmark$ & & & & $\checkmark$ & $\checkmark$ & $\checkmark$ & $\checkmark$ & $\checkmark$ \\
\hline Environmental competencies & & & & & & & & & $\checkmark$ & $\checkmark$ & $\checkmark$ & & \\
\hline Innovation & & & $\checkmark$ & & & & & & & & & & \\
\hline Resource consumption & & & & & & & & & & & & $\checkmark$ & $\checkmark$ \\
\hline Green product & & & $\checkmark$ & & & & & & & & $\checkmark$ & $\checkmark$ & \\
\hline Pollution control & & & $\checkmark$ & $\checkmark$ & $\checkmark$ & & & & & & & $\checkmark$ & $\checkmark$ \\
\hline
\end{tabular}

Table 1 . Sustainability attributes relevant to supplier selection

TOPSIS is most preferred for capturing all objective and subjective criteria (Bhutia \& Phipon, 2012). TOPSIS involves two artificial alternatives being defined as positive- ideal and negativeideal solution. The positive- ideal solution is a solution that maximizes the benefit criteria and minimizes the cost criteria, whereas the negative- ideal solution maximizes the cost criteria and minimizes the benefit criteria (Wang \& Elhag, 2006). The positive- ideal solution has the best level for all attributes considered, whereas the negative ideal solution has the worst 
attribute values. TOPSIS approach selects the alternative that is closest to the positive ideal solution and farthest from the negative- ideal solution.

Thus, this paper intends to adopt the integrated Fuzzy, DEMATEL and TOPSIS method for implementing sustainable supplier selection. It is expected that the proposed model will solve the problems of imprecise data, ambiguous human judgment and uncertainty amongst sustainability criteria while considering all subjective and objective criteria during implementing sustainable supplier selection.

\section{Methodology}

The longitudinal and cross-wise designs were adopted to collect data on supplier selection based on sustainability factors in a gear manufacturing company in this work. The focus was to deduct sustainability factors relevant to the case study and subsequent ranking of suppliers with respect to the sustainability factors. A gear manufacturing company in China was used as the sample population from which the purchasing unit was selected. This is because of accessibility and all sourcing activities were carried out in the purchasing unit. The information used for the study was gathered from archival records and interviews with personnel. The personnel considered in this study were 12 experts/ purchasing managers. The gear manufacturing company under study produces $2 \mathrm{MW}$ wind power gear box and sources for gear wheel shaft as its main raw material. For this study, 7 suppliers are considered as alternatives for providing the gear wheel shaft.

\subsection{Model formulation}

Specific to this model is that a distinction was made between the different levels of sustainability criteria: (1) Sustainability criteria were outlined as social, economic and environmental attributes; and (2) Sustainability sub- criteria represent criteria linked to each alternative supplier (e.g. quality of a particular supplier). Figure 1 shows the proposed model for sustainable supplier selection. 


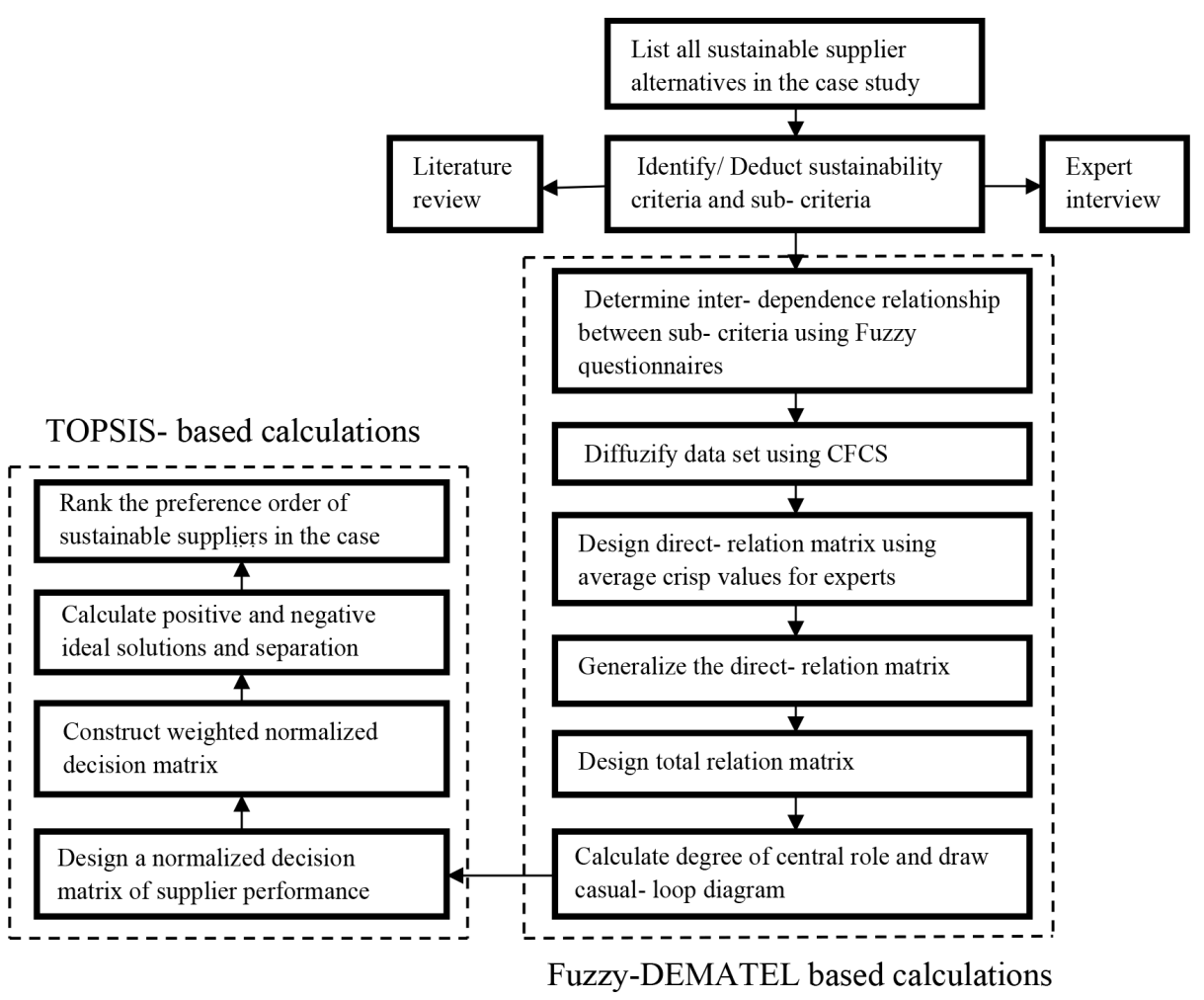

Figure 1. Integrated model for implementing sustainable supplier selection

Within the development of the model, the sustainability factors/ sub- criteria relevant to case, linguistic scale and alternatives were progressively defined.

\subsubsection{Sustainability factors}

All input data on sustainability factors were obtained from a Chinese gear manufacturing company within the period of May 2013 and December 2013 and expressed in numbers/ scores using linguistic scale. The sustainability factors include economic, environmental and social factors. Economic factors consists of cost, quality, OTD, S\&R; Environmental factors consists of EMS, EC, GD and PC while Social factors include RFP, WT, ID, ROS and WS.

\subsubsection{Linguistic scale}

This is defined as a qualitative scale used to collect evaluator's judgment. In this work, two kinds of linguistic scales are applied. The first is the fuzzy linguistic scale having linguistic terms of no influence, very low influence, low influence, high influence and very high influence with respective scores of $0,1,2,3,4$ and triangular fuzzy numbers of $(0,0,0.25)$, $(0,0.25,0.50),(0.25,0.50,0.75),(0.50,0.75,1.00)$ and $(0.75,1.00,1.00)$ respectively. The second is the linguistic scale for the performance of alternatives with respect to the various 
sustainability factors; having linguistic terms of very weak, weak, medium, good and very good with scores of $1,2,3,4$ and 5 respectively.

\subsubsection{Alternatives}

In this model, an alternative was defined as any supplier in the gear manufacturing company. A high level of detail (i.e., alternatives defined as suppliers of specific parts) was used.

In the model, it is assumed that (a) due to standard measurement restrictions, total influence of sustainability criteria should remain constant; (b) expert judgments are ambiguous; (c) input data are imprecise and (d) uncertainty exists among sustainability elements.

\subsection{Fuzzy- DEMATEL based calculations}

This comprises of the computation of direct- relation matrix, generalized relation matrix, total-relation matrix and degree of importance of the deducted sustainability sub- criteria.

The direct- relation matrix is computed by considering the influence of each sustainability subcriterion on other sub- criteria. To obtain the information on the influence of each criterion on other criteria, fuzzy design questionnaires were administered to experts in the company under study and the direct- relation matrix, shown in Table 2, with element $B_{i j}$ was obtained. Where $i, j=1,2,3$ $n$. It should be noted that the membership function of the fuzzy set is applied in triangular form to obtain ideal solutions from group decisions. A triangular fuzzy number can be shown as $q=(a, b, c)$ and the triangular membership function $\tilde{u}_{q}$ is defined as Equation (1). A diffuzification process known as CFCS process which is based on the determination of maximum and minimum fuzzy number range was used to diffuzify the fuzzy set into crisp values. It is deemed to be more effective by researchers for arriving at crisp values when compared to the centroid method (Opricovic \& Tzeng, 2003; Gharakhani, 2012).

$$
\tilde{u}_{q}(y)=\left\{\begin{array}{cc}
0 & \text { if } y<a \\
\frac{(y-a)}{(b-a)} & \text { if } a \leq y \leq b \\
\frac{(c-y)}{(c-b)} & \text { if } b \leq y \leq c \\
0 & \text { if } y>c
\end{array}\right.
$$

According to the membership function $\tilde{u}_{q}$, the total score is calculated with the weighted average. Given that $U$ represents a fuzzy set, the fuzzy evaluation is given by $\tilde{u}_{i j}{ }^{d}=\left(a_{i j}^{d}, b_{i j}^{d}\right.$, $\left.c^{d}{ }_{i j}\right)$ for decision makers $d=(1,2, \ldots n)$ for the degree of influence of sub- criterion $i$ on 
sub- criterion $j$. The CFCS method involves a five- step algorithm described as follows (Gharakhani, 2012):

Step 1: Normalization:

$$
\begin{gathered}
x a_{i j}^{n}=\left(a_{i j}^{n}-\operatorname{minc}_{i j}^{n}\right) / \Delta_{\text {min }}^{\max } \\
x b_{i j}^{n}=\left(b_{i j}^{n}-\operatorname{minc}_{i j}^{n}\right) / \Delta_{\text {min }}^{\max } \\
x c_{i j}^{n}=\left(c_{i j}^{n}-\operatorname{minc}_{i j}^{n}\right) / \Delta_{\min }^{\max } \\
\text { Where } \Delta^{\max }{ }_{\min }=\operatorname{maxa}_{i j}^{n}-\operatorname{minc}_{i j}^{n}
\end{gathered}
$$

Step 2: Compute right (as) and left (cs) normalized values:

$$
\begin{gathered}
x a s_{i j}^{n}=x a_{i j}^{n} /\left(1+x a_{i j}^{n}-x b_{i j}^{n}\right) \\
x c s_{i j}^{n}=x b_{i j}^{n} /\left(1+x b_{i j}^{n}-x c_{i j}^{n}\right)
\end{gathered}
$$

Step 3: Compute total normalized crisp values:

$$
x_{i j}^{n}=\left[x \operatorname{cs}_{i j}^{n}\left(1-x c s^{n}{ }_{i j}\right)+x a s_{i j}^{n} X x a s_{i j}^{n}\right] /\left[1-x c s_{i j}^{n}+x a s_{i j}^{n}\right]
$$

Step 4: Compute crisp values:

$$
u_{i j}^{n}=\operatorname{minc}_{i j}^{n}+x_{i j}^{n} X \Delta_{\min }^{\max }
$$

Step 5: Integrate crisp values:

$$
u_{i j}=1 / p\left(u_{i j}^{1}+u_{i j}^{2}+\ldots+u_{i j}^{p}\right)
$$

\begin{tabular}{|c|c|c|c|}
\hline \multirow{2}{*}{ Sub- criteria } & \multicolumn{3}{|c|}{ Sub- criteria } \\
\cline { 2 - 4 } & $\mathbf{S}_{1}$ & $\mathbf{S}_{2}$ & $\mathbf{S}_{\mathrm{n}}$ \\
\hline $\mathrm{S}_{1}$ & $\mathrm{~B}_{11}$ & $\mathrm{~B}_{12}$ & $\mathrm{~B}_{\mathrm{n} 1}$ \\
\hline $\mathrm{S}_{2}$ & $\mathrm{~B}_{21}$ & $\mathrm{~B}_{22}$ & $\mathrm{~B}_{\mathrm{n} 2}$ \\
\hline $\mathrm{S}_{\mathrm{n}}$ & $\mathrm{B}_{\mathrm{n} 1}$ & $\mathrm{~B}_{\mathrm{n} 2}$ & $\mathrm{~B}_{\mathrm{nn}}$ \\
\hline
\end{tabular}

Table 2. Direct- relation matrix 
It should be noted that the influence of each sub- criterion on others in the case study are calculated from the fuzzy linguistic scale shown in Table 3 below.

\begin{tabular}{|l|c|c|}
\hline Linguistic Term & Score & Triangular fuzzy numbers \\
\hline No influence & 0 & $(0,0,0.25)$ \\
\hline Very low influence & 1 & $(0,0.25,0.50)$ \\
\hline Low influence & 2 & $(0.25,0.50,0.75)$ \\
\hline High influence & 3 & $(0.50,0.75,1.00)$ \\
\hline Very high influence & 4 & $(0.75,1.00,1.00)$ \\
\hline
\end{tabular}

Table 3. Fuzzy linguistic scale for sustainability criteria

A generalized direct- relation matrix was developed as Table 4 with information on Table 2 and has an element $\alpha_{i j}$ representing the mean score influence of each sub-criterion divided by the summation of its influence on other sub- criteria in the case study. It is computed as:

$$
\begin{gathered}
\alpha=\frac{1}{\max _{1 \leq i \leq n} \sum_{j=1}^{n} B i j} \times B \\
\alpha=\left[\alpha_{i j}\right]_{n x n} \\
B=\left[B_{i j}\right]_{n x n}
\end{gathered}
$$

\begin{tabular}{|c|c|c|c|}
\hline \multirow{2}{*}{ Sub- criteria } & \multicolumn{3}{|c|}{ Sub- criteria } \\
\cline { 2 - 4 } & $\mathbf{S}_{\mathbf{1}}$ & $\mathbf{S}_{2}$ & $\mathbf{S}_{\mathbf{n}}$ \\
\hline $\mathrm{S}_{1}$ & $\mathrm{a}_{11}$ & $\mathrm{a}_{12}$ & $\mathrm{a}_{1 \mathrm{n}}$ \\
\hline $\mathrm{S}_{2}$ & $\mathrm{a}_{21}$ & $\mathrm{a}_{22}$ & $\mathrm{a}_{2 \mathrm{n}}$ \\
\hline $\mathrm{S}_{\mathrm{n}}$ & $\mathrm{a}_{\mathrm{n} 1}$ & $\mathrm{a}_{\mathrm{n} 2}$ & $\mathrm{a}_{\mathrm{nn}}$ \\
\hline
\end{tabular}

Table 4. Generalized direct- relation matrix

A total- relation matrix was developed in Table 5 below having element $R_{i j}$.

\begin{tabular}{|c|c|c|c|}
\hline \multirow{2}{*}{ Sub- criteria } & \multicolumn{3}{|c|}{ Sub- criteria } \\
\cline { 2 - 4 } & $\mathbf{S}_{1}$ & $\mathrm{~S}_{2}$ & $\mathrm{~S}_{\mathrm{n}}$ \\
\hline $\mathrm{S}_{1}$ & $\mathrm{R}_{11}$ & $\mathrm{R}_{12}$ & $\mathrm{R}_{\mathrm{n} 1}$ \\
\hline $\mathrm{S}_{2}$ & $\mathrm{R}_{21}$ & $\mathrm{R}_{22}$ & $\mathrm{R}_{\mathrm{n} 2}$ \\
\hline $\mathrm{S}_{\mathrm{n}}$ & $\mathrm{R}_{\mathrm{n} 1}$ & $\mathrm{R}_{\mathrm{n} 2}$ & $\mathrm{R}_{\mathrm{nn}}$ \\
\hline
\end{tabular}

Table 5. Total- relation matrix 
$R_{i j}$ is computed as:

$$
\begin{gathered}
R=\alpha(I-\alpha)-1 \\
R=\left[R_{i j}\right]_{n x n}
\end{gathered}
$$

The degree of central role matrix was developed as shown on Table 6.

\begin{tabular}{|c|c|c|c|c|}
\hline Sub- criteria & W & H & W+H & W-H \\
\hline$S_{1}$ & $W_{1}$ & $H_{1}$ & $(W+H)_{1}$ & $(W-H)_{1}$ \\
\hline$S_{2}$ & $W_{2}$ & $H_{2}$ & $(W+H)_{2}$ & $(W-H)_{2}$ \\
\hline$S_{n}$ & $W_{n}$ & $H_{n}$ & $(W+H)_{n}$ & $(W-H)_{n}$ \\
\hline
\end{tabular}

Table 6. Degree of central role matrix

Where,

$W$ and $H$ represent the sum of rows and sum of columns respectively. They are calculated as:

$$
\begin{gathered}
W=\left[\sum_{j=1}^{n} R i j\right]_{n x 1} \\
H=\left[\sum_{i=1}^{n} R i j\right]_{1 x n}
\end{gathered}
$$

$W+H$ denote the degree of central role used to evaluate the criteria of significance for each sub criterion. $W-H$ denotes the degree of relation used to evaluate the most influential criteria for each sub- criterion. A casual and effect graph can then be drawn with $W+H$ on the horizontal axis and $W-H$ on the vertical axis.

\subsection{TOPSIS based calculations}

The supplier performance with respect to the sustainability criteria were ranked by the experts in the gear manufacturing company under study using the linguistic scale shown in Table 7 below:

\begin{tabular}{|l|c|}
\hline Linguistic Term & Score \\
\hline Very weak & 1 \\
\hline Weak & 2 \\
\hline Medium & 3 \\
\hline Good & 4 \\
\hline Very good & 5 \\
\hline
\end{tabular}

Table 7. Linguistic scale for alternatives 
The experts then compare the alternative suppliers under each criterion to establish the decision matrix. Table 8 is developed from the established decision matrix with element $P_{i j}$ which represents the normalized evaluation index for the alternative suppliers as shown above:

\begin{tabular}{|c|c|c|c|c|}
\hline \multirow{2}{*}{ Alternatives } & \multicolumn{4}{|c|}{ Sub- criteria } \\
\cline { 2 - 5 } & $\mathbf{S}_{1}$ & $\mathbf{S}_{2}$ & $\mathbf{S}_{3}$ & $\mathbf{S}_{\mathbf{n}}$ \\
\hline $\mathrm{A}_{1}$ & $\mathrm{P}_{11}$ & $\mathrm{P}_{12}$ & $\mathrm{P}_{13}$ & $\mathrm{P}_{1 \mathrm{n}}$ \\
\hline $\mathrm{A}_{2}$ & $\mathrm{P}_{21}$ & $\mathrm{P}_{22}$ & $\mathrm{P}_{23}$ & $\mathrm{P}_{2 \mathrm{n}}$ \\
\hline $\mathrm{A}_{\mathrm{m}}$ & $\mathrm{P}_{\mathrm{m} 1}$ & $\mathrm{P}_{\mathrm{m} 2}$ & $\mathrm{P}_{\mathrm{m} 3}$ & $\mathrm{P}_{\mathrm{mn}}$ \\
\hline
\end{tabular}

Table 8. Normalized decision matrix

$P_{i j}$ is computed as:

$$
P_{i j}=\frac{g_{i j}}{\left(g^{2}\right)^{0.5}}
$$

Where, $g_{i j}$ is the performance of each alternative with respect to each criterion. The weighted normalized decision matrix $V_{i j}$ is calculated as:

$$
V_{i j}=P_{i j} \mathrm{x} \alpha_{i j}
$$

The ideal $\left(V_{j}^{+}\right)$and negative ideal $\left(V_{j}^{-}\right)$solutions are determined as:

$$
\begin{gathered}
V_{j}^{+}=\left\{v_{i}^{+} \ldots v_{n}^{+}\right\}=\left[\left(\max v_{i j} \mid i \in I^{\prime}\right),\left(\min v_{i j} \mid i \in I^{\prime \prime}\right)\right] \\
V_{j}^{-}=\left\{v_{i}^{-} \ldots v_{n}^{-}\right\}=\left[\left(\min v_{i j} \mid i \in I^{\prime}\right),\left(\max v_{i j} \mid i \in I^{\prime \prime}\right)\right]
\end{gathered}
$$

Where $I^{\prime}$ is associated with advantage criteria, and $I^{\prime \prime}$ is associated with cost criteria.

The separation measures $\left(d_{i}^{+}\right.$and $\left.d_{i}^{-}\right)$are computed using the $\mathrm{n}$ - dimensional Euclidean distance for the alternatives as:

$$
d_{i}^{+}=\left\{\sum_{j=1}^{n}(v i j-v j)^{2}\right\}^{0.5}
$$

Where $i=1,2, \ldots, m ; v_{j}\left(\right.$ in Equation 12) $=v_{j}^{+}$

$$
d_{i}^{-}=\left\{\sum_{j=1}^{n}(v i j-v j)^{2}\right\}^{0.5}
$$

Where $i=1,2, \ldots, m ; v_{j}($ in Equation 13$)=v_{j}^{-}$ 
The relative closeness of the alternatives $\left(a_{j}\right)$ to the ideal $\left(A^{*}\right)$ solution is computed as:

$$
L_{i}=\frac{d_{i}^{-}}{d_{i}^{-}+d_{i}^{+}} \quad 0 \leq L_{i} \leq 1
$$

Where $I^{\prime}$ is associated with advantage criteria, and $I^{\prime}$ ' is associated with cost criteria. Finally, the alternative suppliers are ranked with respect to their relative closeness to the ideal solution in order of preference.

\section{Results and Discussion}

Data collected in this work were analyzed using Microsoft Excel and MATLAB. Table 9 shows the direct- relation matrix of sustainability sub- criteria in the case study.

\begin{tabular}{|l|c|c|c|c|c|c|c|c|c|c|c|c|c|}
\hline & WT & GD & EMS & ROS & WS & Quality & RFP & Cost & ID & EC & PC & OTD & S\&R \\
\hline WT & 0 & 2.666 & 3.583 & 1.916 & 0.583 & 0.666 & 2.916 & 0.416 & 0.083 & 0.416 & 0.416 & 0.75 & 1.833 \\
\hline GD & 3.583 & 0 & 3.583 & 1.833 & 0.083 & 1.916 & 1.583 & 0.416 & 0.166 & 0.583 & 0.916 & 0.833 & 2.916 \\
\hline EMS & 2.666 & 3.833 & 0 & 2.833 & 0.666 & 0.416 & 1.916 & 0.583 & 0.666 & 0.083 & 1.833 & 0.416 & 2.083 \\
\hline ROS & 2.833 & 2.417 & 3.583 & 0 & 0.416 & 0.583 & 0.416 & 0.083 & 1.916 & 2.666 & 3.583 & 2.916 & 3.666 \\
\hline WS & 1.916 & 1.083 & 0.916 & 1.916 & 0 & 1.083 & 2.333 & 2.417 & 2.167 & 2.083 & 3.167 & 3.167 & 2.833 \\
\hline Quality & 1.083 & 0.083 & 0.083 & 0.666 & 0.583 & 0 & 0.583 & 0.583 & 0.083 & 2.833 & 1.916 & 2.666 & 1.916 \\
\hline RFP & 0.416 & 1.916 & 2.083 & 2.333 & 1.916 & 0.083 & 0 & 3.333 & 1.916 & 3.083 & 2.916 & 2.666 & 0.416 \\
\hline Cost & 0.083 & 0.583 & 0.083 & 0.416 & 0.666 & 0.166 & 0.75 & 0 & 1.583 & 2.417 & 3.166 & 1.833 & 3.083 \\
\hline ID & 0.916 & 1.066 & 2.666 & 1.916 & 0.416 & 0.833 & 1.083 & 0.75 & 0 & 3.333 & 0.008 & 0.583 & 2.666 \\
\hline EC & 1.833 & 0.416 & 0.583 & 1.583 & 0.916 & 0.916 & 0.666 & 0.333 & 0.583 & 0 & 2.666 & 0.083 & 0.416 \\
\hline PC & 0.583 & 0.666 & 0.416 & 0.916 & 0.083 & 0.583 & 0.916 & 0.833 & 0.666 & 0.417 & 0 & 0.666 & 3.833 \\
\hline OTD & 0.416 & 0.083 & 0.916 & 2.333 & 1.066 & 0.666 & 2.066 & 0.583 & 0.333 & 0.833 & 0.916 & 0 & 2.916 \\
\hline S\&R & 0.666 & 0.083 & 0.416 & 1.916 & 0.583 & 0.083 & 0.666 & 0.916 & 0.416 & 0.333 & 0.583 & 1.083 & 0 \\
\hline
\end{tabular}

Table 9. Direct- relation matrix

The data collected from experts in the case study using fuzzy questionnaires were diffuzified using Equations (2), (3), (4), (5), (6), (7), (8), (9) and (10) into crisp values. A simple average method was used to calculate the averages of the crisp values of the influence of each sub- criterion on other sub- criteria for all the experts/ purchasing managers in the gear manufacturing company under study to give Table 9. A total- relation matrix as shown in Table 10 was developed using Equations (11), (12), (13), (14) and (15). Table 10 which shows the degree role matrix was also calculated with elements $W, H, W+H$ and $W-H$. 


\begin{tabular}{|c|c|c|c|c|c|c|c|c|c|c|c|c|c|c|}
\hline & WT & GD & EMS & ROS & ws & $\begin{array}{c}\text { Quali } \\
\text { ty }\end{array}$ & RFP & Cost & ID & EC & PC & OTD & $S \& R$ & Total \\
\hline WT & $\begin{array}{c}0.07 \\
5\end{array}$ & $\begin{array}{c}0.15 \\
9\end{array}$ & $\begin{array}{c}0.19 \\
9\end{array}$ & $\begin{array}{c}0.14 \\
9\end{array}$ & $\begin{array}{c}0.05 \\
2\end{array}$ & $\begin{array}{c}0.05 \\
2\end{array}$ & $\begin{array}{c}0.15 \\
8\end{array}$ & $\begin{array}{c}0.06 \\
6\end{array}$ & $\begin{array}{c}0.04 \\
4\end{array}$ & $\begin{array}{c}0.07 \\
6\end{array}$ & $\begin{array}{c}0.09 \\
8\end{array}$ & $\begin{array}{c}0.09 \\
0\end{array}$ & $\begin{array}{c}0.16 \\
5\end{array}$ & 1.389 \\
\hline GD & $\begin{array}{c}0.19 \\
1\end{array}$ & $\begin{array}{c}0.07 \\
5\end{array}$ & $\begin{array}{c}0.20 \\
1\end{array}$ & $\begin{array}{c}0.14 \\
9\end{array}$ & $\begin{array}{c}0.03 \\
6\end{array}$ & $\begin{array}{c}0.09 \\
3\end{array}$ & $\begin{array}{c}0.12 \\
0\end{array}$ & $\begin{array}{c}0.06 \\
4\end{array}$ & $\begin{array}{c}0.04 \\
4\end{array}$ & $\begin{array}{c}0.08 \\
1\end{array}$ & $\begin{array}{c}0.11 \\
4\end{array}$ & $\begin{array}{c}0.09 \\
4\end{array}$ & $\begin{array}{c}0.20 \\
4\end{array}$ & 1.472 \\
\hline EMS & $\begin{array}{c}0.16 \\
7\end{array}$ & $\begin{array}{c}0.19 \\
9\end{array}$ & $\begin{array}{c}0.09 \\
5\end{array}$ & $\begin{array}{c}0.18 \\
1\end{array}$ & $\begin{array}{c}0.05 \\
4\end{array}$ & $\begin{array}{c}0.04 \\
9\end{array}$ & $\begin{array}{c}0.13 \\
0\end{array}$ & $\begin{array}{c}0.07 \\
0\end{array}$ & $\begin{array}{c}0.06 \\
4\end{array}$ & $\begin{array}{c}0.06 \\
9\end{array}$ & $\begin{array}{c}0.14 \\
5\end{array}$ & $\begin{array}{c}0.08 \\
3\end{array}$ & $\begin{array}{c}0.18 \\
7\end{array}$ & 1.498 \\
\hline ROS & $\begin{array}{c}0.18 \\
6\end{array}$ & $\begin{array}{c}0.16 \\
1\end{array}$ & $\begin{array}{c}0.21 \\
9\end{array}$ & $\begin{array}{c}0.11 \\
3\end{array}$ & $\begin{array}{c}0.05 \\
4\end{array}$ & $\begin{array}{c}0.06 \\
1\end{array}$ & $\begin{array}{c}0.09 \\
9\end{array}$ & $\begin{array}{c}0.07 \\
0\end{array}$ & $\begin{array}{c}0.11 \\
0\end{array}$ & $\begin{array}{c}0.16 \\
1\end{array}$ & $\begin{array}{c}0.21 \\
6\end{array}$ & $\begin{array}{c}0.16 \\
9\end{array}$ & $\begin{array}{c}0.26 \\
5\end{array}$ & 1.891 \\
\hline WS & $\begin{array}{c}0.14 \\
6\end{array}$ & $\begin{array}{c}0.11 \\
2\end{array}$ & $\begin{array}{c}0.12 \\
7\end{array}$ & $\begin{array}{c}0.17 \\
3\end{array}$ & $\begin{array}{c}0.04 \\
4\end{array}$ & $\begin{array}{c}0.07 \\
5\end{array}$ & $\begin{array}{c}0.15 \\
8\end{array}$ & $\begin{array}{c}0.15 \\
5\end{array}$ & $\begin{array}{c}0.12 \\
8\end{array}$ & $\begin{array}{c}0.16 \\
1\end{array}$ & $\begin{array}{c}0.21 \\
6\end{array}$ & $\begin{array}{c}0.19 \\
1\end{array}$ & $\begin{array}{c}0.24 \\
3\end{array}$ & 1.934 \\
\hline Quality & $\begin{array}{c}0.07 \\
6\end{array}$ & $\begin{array}{c}0.03 \\
6\end{array}$ & $\begin{array}{c}0.00 \\
4\end{array}$ & $\begin{array}{c}0.07 \\
8\end{array}$ & $\begin{array}{c}0.04 \\
3\end{array}$ & $\begin{array}{c}0.01 \\
9\end{array}$ & $\begin{array}{c}0.06 \\
0\end{array}$ & $\begin{array}{c}0.06 \\
1\end{array}$ & $\begin{array}{c}0.02 \\
9\end{array}$ & $\begin{array}{c}0.12 \\
4\end{array}$ & $\begin{array}{c}0.12 \\
4\end{array}$ & $\begin{array}{c}0.13 \\
0\end{array}$ & $\begin{array}{c}0.13 \\
7\end{array}$ & .969 \\
\hline RFP & $\begin{array}{c}0.10 \\
2\end{array}$ & $\begin{array}{c}0.13 \\
9\end{array}$ & $\begin{array}{c}0.16 \\
1\end{array}$ & $\begin{array}{c}0.18 \\
0\end{array}$ & $\begin{array}{c}0.10 \\
4\end{array}$ & $\begin{array}{c}0.04 \\
4\end{array}$ & $\begin{array}{c}0.07 \\
7\end{array}$ & $\begin{array}{c}0.18 \\
2\end{array}$ & $\begin{array}{c}0.12 \\
0\end{array}$ & $\begin{array}{c}0.21 \\
0\end{array}$ & $\begin{array}{c}0.21 \\
0\end{array}$ & $\begin{array}{c}0.16 \\
9\end{array}$ & $\begin{array}{c}0.16 \\
4\end{array}$ & 1.868 \\
\hline Cost & $\begin{array}{c}0.04 \\
7\end{array}$ & $\begin{array}{c}0.05 \\
4\end{array}$ & $\begin{array}{c}0.05 \\
0\end{array}$ & $\begin{array}{c}0.07 \\
5\end{array}$ & $\begin{array}{c}0.04 \\
6\end{array}$ & $\begin{array}{c}0.02 \\
7\end{array}$ & $\begin{array}{c}0.06 \\
7\end{array}$ & $\begin{array}{c}0.04 \\
5\end{array}$ & $\begin{array}{c}0.08 \\
3\end{array}$ & $\begin{array}{c}0.16 \\
4\end{array}$ & $\begin{array}{c}0.16 \\
4\end{array}$ & $\begin{array}{c}0.10 \\
5\end{array}$ & $\begin{array}{c}0.18 \\
4\end{array}$ & 1.115 \\
\hline ID & $\begin{array}{c}0.09 \\
8\end{array}$ & $\begin{array}{c}0.09 \\
5\end{array}$ & $\begin{array}{c}0.15 \\
6\end{array}$ & $\begin{array}{c}0.14 \\
1 \\
\end{array}$ & $\begin{array}{c}0.04 \\
4\end{array}$ & $\begin{array}{c}0.05 \\
5\end{array}$ & $\begin{array}{c}0.09 \\
0\end{array}$ & $\begin{array}{c}0.07 \\
8 \\
\end{array}$ & $\begin{array}{c}0.03 \\
5\end{array}$ & $\begin{array}{c}0.08 \\
3\end{array}$ & $\begin{array}{c}0.08 \\
3\end{array}$ & $\begin{array}{c}0.07 \\
6\end{array}$ & $\begin{array}{c}0.18 \\
1\end{array}$ & 1.223 \\
\hline EC & $\begin{array}{c}0.10 \\
8\end{array}$ & $\begin{array}{c}0.06 \\
0\end{array}$ & $\begin{array}{c}0.07 \\
4\end{array}$ & $\begin{array}{c}0.11 \\
0\end{array}$ & $\begin{array}{c}0.54 \\
3\end{array}$ & $\begin{array}{c}0.05 \\
3\end{array}$ & $\begin{array}{c}0.68 \\
8\end{array}$ & $\begin{array}{c}0.15 \\
1\end{array}$ & $\begin{array}{c}0.05 \\
4\end{array}$ & $\begin{array}{c}0.15 \\
8\end{array}$ & $\begin{array}{c}0.15 \\
8\end{array}$ & $\begin{array}{c}0.05 \\
6\end{array}$ & $\begin{array}{c}0.10 \\
6\end{array}$ & 1.834 \\
\hline PC & $\begin{array}{c}0.05 \\
4\end{array}$ & $\begin{array}{c}0.05 \\
2\end{array}$ & $\begin{array}{c}0.05 \\
3\end{array}$ & $\begin{array}{c}0.07 \\
6\end{array}$ & $\begin{array}{c}0.02 \\
1\end{array}$ & $\begin{array}{c}0.03 \\
4\end{array}$ & $\begin{array}{c}0.06 \\
1\end{array}$ & $\begin{array}{c}0.05 \\
7\end{array}$ & $\begin{array}{c}0.04 \\
4\end{array}$ & $\begin{array}{c}0.04 \\
3\end{array}$ & $\begin{array}{c}0.04 \\
3\end{array}$ & $\begin{array}{c}0.05 \\
9\end{array}$ & $\begin{array}{c}0.18 \\
4\end{array}$ & 0.786 \\
\hline OTD & $\begin{array}{c}0.06 \\
3\end{array}$ & $\begin{array}{c}0.04 \\
9\end{array}$ & $\begin{array}{c}0.08 \\
6\end{array}$ & $\begin{array}{c}0.13 \\
9\end{array}$ & $\begin{array}{c}0.06 \\
1\end{array}$ & $\begin{array}{c}0.04 \\
3\end{array}$ & $\begin{array}{c}0.11 \\
1 \\
\end{array}$ & $\begin{array}{c}0.06 \\
3\end{array}$ & $\begin{array}{c}0.08 \\
1\end{array}$ & $\begin{array}{c}0.09 \\
9\end{array}$ & $\begin{array}{c}0.09 \\
9\end{array}$ & $\begin{array}{c}0.05 \\
4\end{array}$ & $\begin{array}{c}0.17 \\
7\end{array}$ & 1.190 \\
\hline$S \& R$ & $\begin{array}{c}0.05 \\
3\end{array}$ & $\begin{array}{c}0.03 \\
3\end{array}$ & $\begin{array}{c}0.05 \\
1\end{array}$ & $\begin{array}{c}0.10 \\
1\end{array}$ & $\begin{array}{c}0.03 \\
5\end{array}$ & $\begin{array}{c}0.01 \\
6\end{array}$ & $\begin{array}{c}0.05 \\
0\end{array}$ & $\begin{array}{c}0.03 \\
6\end{array}$ & $\begin{array}{c}0.04 \\
4\end{array}$ & $\begin{array}{c}0.06 \\
2\end{array}$ & $\begin{array}{c}0.06 \\
2\end{array}$ & $\begin{array}{c}0.06 \\
9\end{array}$ & $\begin{array}{c}0.06 \\
4\end{array}$ & 0.672 \\
\hline Total & $\begin{array}{c}1.37 \\
0\end{array}$ & $\begin{array}{c}1.23 \\
1\end{array}$ & $\begin{array}{c}1.52 \\
4\end{array}$ & $\begin{array}{c}1.67 \\
0\end{array}$ & $\begin{array}{c}0.65 \\
2\end{array}$ & $\begin{array}{c}0.62 \\
8\end{array}$ & $\begin{array}{c}1.87 \\
5\end{array}$ & $\begin{array}{c}1.10 \\
4\end{array}$ & $\begin{array}{c}0.88 \\
7\end{array}$ & $\begin{array}{c}1.49 \\
6\end{array}$ & $\begin{array}{c}1.73 \\
7\end{array}$ & 1.35 & $\begin{array}{c}2.25 \\
5\end{array}$ & \\
\hline
\end{tabular}

Table 10. Total- relation matrix

Table 11 showing the degree role matrix was also calculated with elements $W, H, W+H$ and $W-H$.

\begin{tabular}{|l|c|c|c|c|c|c|}
\hline & $\mathbf{W}$ & $\mathbf{H}$ & $\mathbf{W + H}$ & Ranking & W-H & Ranking \\
\hline WT & 1.3894 & 1.3708 & 2.7602 & 5 & 0.0186 & 7 \\
\hline GD & 1.4723 & 1.2316 & 2.7039 & 6 & 0.2407 & 5 \\
\hline EMS & 1.4984 & 1.5240 & 3.0224 & 4 & -0.0256 & 10 \\
\hline ROS & 1.8918 & 1.6709 & 3.5627 & 2 & 0.2209 & 6 \\
\hline WS & 1.9343 & 0.6525 & 2.5868 & 7 & 1.2818 & 1 \\
\hline Quality & 0.9694 & 0.6285 & 1.5979 & 13 & 0.3409 & 2 \\
\hline RFP & 1.8683 & 1.8759 & 3.7442 & 1 & -0.0076 & 9 \\
\hline Cost & 1.1153 & 1.104 & 2.2193 & 11 & 0.0113 & 8 \\
\hline ID & 1.2231 & 0.8877 & 2.1108 & 12 & 0.3354 & 4 \\
\hline EC & 1.8345 & 1.4968 & 3.3313 & 3 & 0.3377 & 3 \\
\hline PC & 0.7861 & 1.7375 & 2.5236 & 8 & -0.9514 & 12 \\
\hline OTD & 1.1302 & 1.3500 & 2.4802 & 9 & -0.2198 & 11 \\
\hline S\&R & 0.0672 & 2.2554 & 2.3226 & 10 & -2.1881 & 13 \\
\hline
\end{tabular}

Table 11. Degree of central role matrix 
The sum of each row of the sub- criteria $(W)$ and sum of each column of sub- criteria $(H)$ were calculated using Equations (16) and (17) respectively. Then, the degree of importance/ central role $(W+H)$ and the degree of influence/ relation $(W-H)$ were likewise calculated for the different sub- criteria in the case study.

Using the degree of significance $(W+H)$ as depicted on Table 11, the order of significance/ importance of the sub- criteria in the company under study are identified as follows: RFP> ROS $>$ EC > EMS > WT> GD>WS> PC> OTD> S\&R > Cost> ID> Quality. Respect for Policy (RFP) ranks as the most important sub- criterion with score 3. 7442. RFP represents what the company under study stands for with respect to human and workplace rights. The company formally endorsed the UN guiding principles on Business and Human rights thus the emphasis of RFP in the company. In the case study, RFP places a check on child labor, migrant labor and other vices that could lead to court cases thereby destroying company image and causing money loss. Other significant criteria for sustainable supplier selection as shown in the case study are ROS, EC, EMS and WT with scores of 3.5627, 3.3313, 3.0224 and 2.7662 respectively. In the case study, ROS involves the company being fair and transparent to its owners, thereby carrying out operations not to waste or deteriorate the company but for the highest benefits of the stakeholders. Also, ROS covers social participation by supporting and promoting activities which maintain good tradition and culture e.g. providing scholarships. Thus, in the case study ROS assists the company in image- building and is very important. Figure 2 shows the degree of importance of sustainability criteria in the company.

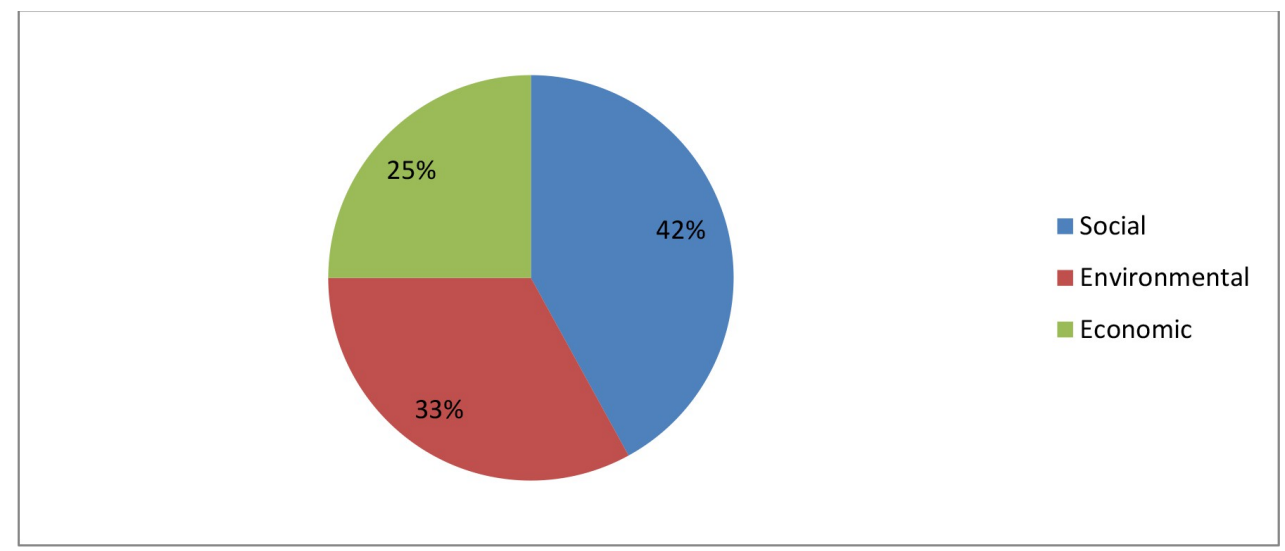

Figure 2. Degree of importance of sustainability criteria in the case study

In the case study, environmental competencies include knowledge towards effective environmental management. The system to reflect the environmental action plan set by the management and provides feedback on the results of their actions to management is termed the Environmental management system in the case study. Quality and cost are the least important criteria in the case study. This could be as a result of the company operating to serve different categories of customers who can afford different quality and price ranges. As 
shown in Figure 2, Social criteria have the highest percentage of $42 \%$ and are ranked the most important criteria. This could be as a result of the company regarding respect of policy, rights of stakeholders, worker's training, work safety and information disclosure as very essential to its image- building and avoidance of money loss.

However, the degree of significance does not provide managers with insights during implementing sustainable supplier selection. It should be noted that $(W-H)_{i}$ shows the net effect that a sub-criterion $i$ contributes to the system in the case study. Thus, the degree of influence provides managers the insight needed during implementing sustainable supplier selection. It is assumed that a sub-criterion $i$ is a net causer when $(W-H)_{i}$ is positive and a net receiver when $(W-H)_{i}$ is negative. A casual and effect graph shown in Figure 3 was drawn with $W+H$ on the horizontal axis and $W-H$ on the vertical axis to show the influence of the different sub- criteria on others.

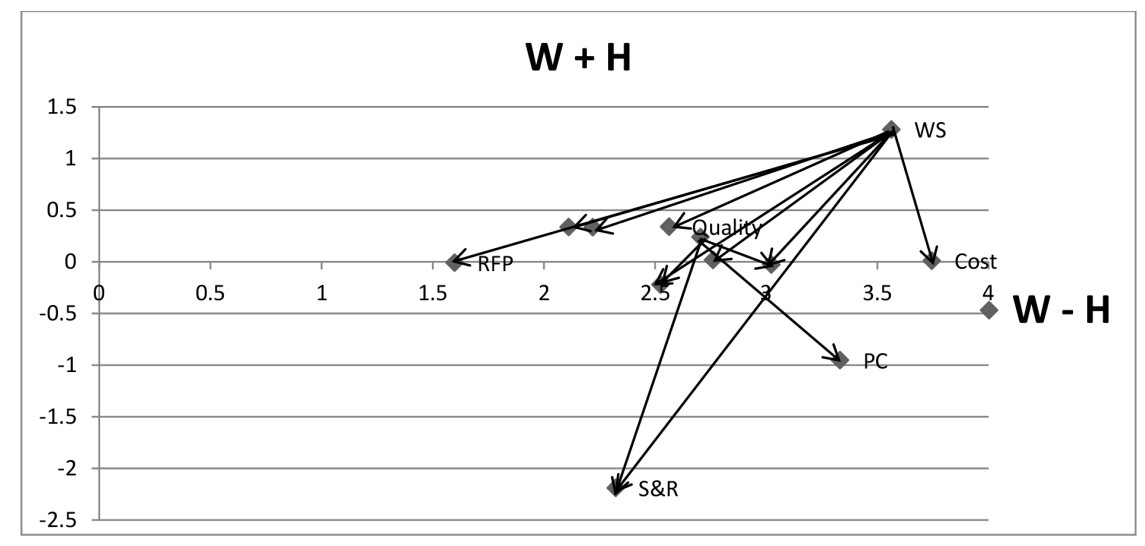

Figure 3. A casual and effect graph of sub- criteria for sustainable Supplier Selection in the company under study

The highest net causers as shown in Figure 3 above are WS and quality with scores of 1.2818 and 0.3409 respectively. The highest net causers are invariably the most influential criteria in the case study, although they have been ranked low with regards to degree of significance/ importance. This implies that to select the best sustainable supplier in the gear manufacturing company under study, it is suggested that emphasis should be placed on work safety and quality of the respective suppliers. This is because, quality and work safety highly influences all the other sustainability criteria although they are not the most important sub- criteria.

The normalized decision matrix shown below in Table 12 was drawn using Equation (18). The purchasing managers in the gear manufacturing company did not disclose the real data of the supplier performance with regards to the sustainability sub- criteria. The data on supplier performance was generated and evaluated using the linguistic scale on Table 7. The supplier performances were the average performance as evaluated by the purchasing managers. A 
simple average method was used to calculate the average supplier performance over a period of 7 months for the different supplier alternatives.

\begin{tabular}{|l|c|c|c|c|c|c|c|}
\hline & $\mathbf{A}_{\mathbf{1}}$ & $\mathbf{A}_{\mathbf{2}}$ & $\mathbf{A}_{\mathbf{3}}$ & $\mathbf{A}_{\mathbf{4}}$ & $\mathbf{A}_{\mathbf{5}}$ & $\mathbf{A}_{\mathbf{6}}$ & $\mathbf{A}_{\mathbf{7}}$ \\
\hline WT & 0.4287 & 0.3429 & 0.4287 & 0.3429 & 0.1714 & 0.4287 & 0.4287 \\
\hline GD & 0.4390 & 0.5488 & 0.4390 & 0.3292 & 0.2195 & 0.3292 & 0.2195 \\
\hline EMS & 0.3162 & 0.5270 & 0.3162 & 0.3162 & 0.3162 & 0.2108 & 0.5270 \\
\hline ROS & 0.5025 & 0.4020 & 0.4020 & 0.2010 & 0.5025 & 0.2010 & 0.3015 \\
\hline WS & 0.3638 & 0.1212 & 0.2425 & 0.4850 & 0.6063 & 0.3638 & 0.2425 \\
\hline Quality & 0.3333 & 0.4444 & 0.5555 & 0.3333 & 0.3333 & 0.3333 & 0.2222 \\
\hline RFP & 0.2603 & 0.2603 & 0.5207 & 0.5207 & 0.3905 & 0.1301 & 0.3905 \\
\hline Cost & 0.2773 & 0.4160 & 0.4160 & 0.5547 & 0.2773 & 0.1386 & 0.4160 \\
\hline ID & 0.2500 & 0.2500 & 0.3750 & 0.3750 & 0.2500 & 0.3750 & 0.6250 \\
\hline EC & 0.3831 & 0.2873 & 0.3831 & 0.2873 & 0.4789 & 0.2873 & 0.4789 \\
\hline PC & 0.4288 & 0.5360 & 0.2144 & 0.2144 & 0.5360 & 0.2144 & 0.3216 \\
\hline OTD & 0.3179 & 0.4239 & 0.1060 & 0.2120 & 0.5299 & 0.5299 & 0.3179 \\
\hline S\&R & 0.3939 & 0.1313 & 0.1313 & 0.3939 & 0.3939 & 0.6565 & 0.2626 \\
\hline
\end{tabular}

Table 12. Normalized decision matrix

Table 13 showing weighted normalized decision matrix was drawn using Equation (19) and information/ data on Table 12.

\begin{tabular}{|l|c|c|c|c|c|c|c|c|c|c|c|c|c|}
\hline & WT & GD & EMS & ROS & WS & Quality & RFP & Cost & ID & EC & PC & OTD & S\&R \\
\hline A1 & 0.016 & 0.025 & 0.017 & 0.034 & 0.043 & 0.013 & 0.023 & 0.022 & 0.016 & 0.010 & 0.038 & 0.038 & 0.058 \\
\hline A2 & 0.013 & 0.031 & 0.028 & 0.027 & 0.014 & 0.018 & 0.023 & 0.033 & 0.016 & 0.007 & 0.048 & 0.050 & 0.019 \\
\hline A3 & 0.016 & 0.025 & 0.017 & 0.027 & 0.028 & 0.023 & 0.047 & 0.033 & 0.024 & 0.010 & 0.018 & 0.013 & 0.019 \\
\hline A4 & 0.013 & 0.019 & 0.017 & 0.001 & 0.058 & 0.013 & 0.035 & 0.044 & 0.024 & 0.007 & 0.018 & 0.025 & 0.058 \\
\hline A5 & 0.006 & 0.012 & 0.017 & 0.034 & 0.072 & 0.013 & 0.012 & 0.022 & 0.016 & 0.013 & 0.047 & 0.063 & 0.058 \\
\hline A6 & 0.016 & 0.019 & 0.011 & 0.013 & 0.043 & 0.013 & 0.012 & 0.011 & 0.024 & 0.007 & 0.018 & 0.063 & 0.099 \\
\hline A7 & 0.016 & 0.012 & 0.028 & 0.020 & 0.028 & 0.009 & 0.035 & 0.033 & 0.041 & 0.013 & 0.028 & 0.038 & 0.099 \\
\hline
\end{tabular}

Table 13. Weighted normalized decision matrix

The positive ideal $\left(V_{j}^{+}\right)$and negative ideal $\left(V_{j}^{-}\right)$solutions are determined using Equations (20) and (21) respectively and stated on Table 14.

\begin{tabular}{|l|c|c|c|c|c|c|c|c|c|c|c|c|c|}
\hline & WT & GD & EMS & ROS & WS & Quality & RFP & Cost & ID & EC & PC & OTD & S\&R \\
\hline$V_{j}^{+}$ & 0.016 & 0.031 & 0.028 & 0.034 & 0.072 & 0.023 & 0.047 & 0.011 & 0.041 & 0.013 & 0.048 & 0.013 & 0.099 \\
\hline$V_{j}^{-}$ & 0.006 & 0.019 & 0.011 & 0.013 & 0.014 & 0.009 & 0.012 & 0.044 & 0.016 & 0.007 & 0.018 & 0.063 & 0.019 \\
\hline
\end{tabular}

Table 14. Ideal positive and negative solutions 
The positive- ideal solution is a solution that maximizes the benefit criteria and minimizes the cost criteria, whereas the negative- ideal solution maximizes the cost criteria and minimizes the benefit criteria (Wang \& Elhag, 2006). The positive- ideal solution has the best level for all attributes considered, whereas the negative ideal solution has the worst attribute values. The separation measures $\left(d_{i}^{+}\right.$and $\left.d_{i}^{-}\right)$were computed using the $\mathrm{n}$ - dimensional Euclidean distance for the alternatives using Equations (22) and (23). The relative closeness to the ideal solutions $L_{i}$ (TOPSIS index) were calculated using Equation (24). The final performance indices for the sustainable supplier alternatives were computed as shown in Table 15 and used to rank the respective suppliers.

\begin{tabular}{|c|c|c|c|c|c|}
\hline & $\boldsymbol{d}_{i}^{+}$ & $\boldsymbol{d}_{i}^{-}$ & $\boldsymbol{d}_{i}^{+}+\boldsymbol{d}_{i}^{-}$ & $\boldsymbol{L}_{\boldsymbol{i}}$ & Ranking \\
\hline $\mathrm{A}_{1}$ & 0.069 & 0.067 & 0.137 & 0.496 & 4 \\
\hline $\mathrm{A}_{2}$ & 0.113 & 0.045 & 0.158 & 0.286 & 7 \\
\hline $\mathrm{A}_{3}$ & 0.100 & 0.067 & 0.168 & 0.403 & 6 \\
\hline $\mathrm{A}_{4}$ & 0.071 & 0.075 & 0.147 & 0.512 & 2 \\
\hline $\mathrm{A}_{5}$ & 0.082 & 0.081 & 0.164 & 0.496 & 3 \\
\hline $\mathrm{A}_{6}$ & 0.082 & 0.091 & 0.174 & 0.527 & 1 \\
\hline $\mathrm{A}_{7}$ & 0.065 & 0.055 & 0.121 & 0.461 & 5 \\
\hline
\end{tabular}

Table 15. Final performance indices of sustainable suppliers

The final performance indices of the alternative suppliers were used to rank the suppliers in the gear manufacturing company under study; $A_{6}$ is identified as the best possible sustainable supplier with a relative closeness to the ideal solution $L_{i}$ of 0.527 . This is as a result of $A_{6}$ being closest to the positive ideal solution and farthest from the negative- ideal solution.

\section{Conclusion}

Globally, manufacturing firms compete in a complex and rapidly changing environment. An effective supplier selection process is a critical success factor for manufacturing firms in a complex environment. Although capturing all subjective and objective criteria in a system seems crucial to ensure accurate calculations in decision making, no literature exists at the moment on model capable of capturing all subjective and objective criteria in fuzzy environment to accurately incorporate sustainability factors in supplier selection.

In this work, a novel model based on integrated multi-criteria decision making (MCDM) methods capable of capturing all objective and subjective criteria is developed to accurately incorporate sustainability in supplier selection in fuzzy environment. The developed novel model employs DEMATEL and fuzzy logic to find the mutual relationships of interdependencies and strength of interdependence within sustainability factors relevant to supplier selection in 
fuzzy environment. Then, TOPSIS most preferred for capturing all objective and subjective criteria is applied to choose the best possible sustainable supplier. A gear manufacturing company, an original equipment manufacturer (OEM) was proposed as a case study to provide insights to the developed model and for practical applications.

RFP ranks as the most important sub- criterion with 3. 7442. RFP represents what the company under study stands for with respect to human and workplace rights. The company under study formally endorsed the UN guiding principles on Business and Human rights thus placing high importance of RFP in the company. RFP places a check on child labor, migrant labor and other vices that could lead to court cases thereby destroying company image and causing money loss in the case study. Other important criteria for sustainable supplier selection in the case study are ROS, EC, EMS and WT with scores of 3.5627, 3.3313, 3.0224 and 2.7662 respectively. Quality and cost are the least important criteria in the company under study. This could be as a result of the company operating to serve different categories of customers who can afford different quality and price ranges. Social criteria have the highest percentage of $42 \%$ and are termed the most important criteria. This could be a result of the company regarding social sub- criteria including respect of policy, rights of stakeholders, worker's training, work safety and information disclosure as very essential to its imagebuilding and avoidance of money loss.

However, degree of influence provides managers the insight needed during implementing sustainable supplier selection. The highest net causers are work safety (WS) and quality with scores of 1.2818 and 0.3409 respectively. The highest net causers are invariably the most influential criteria, although they are not the most important sub- criteria. This implies that to select the best sustainable supplier, it is suggested that emphasis should be placed on work safety and quality of the respective suppliers; quality and work safety influences all the other sustainability criteria although they are not the most important sub- criteria. The final performance indices of the alternative suppliers were used to rank the suppliers in the gear manufacturing company under study; $A_{6}$ is identified as the best possible sustainable supplier with a relative closeness to the ideal solution $L_{i}$ of 0.527 . This is as a result of $A_{6}$ being closest to the positive ideal solution and farthest from the negative- ideal solution during implementing sustainable supplier selection in the case study.

It should be noted that the proposed model is precise given its level of details. Model complexity due to the level of detail of components and assumptions makes it suitable to be applied in other supply chains. 


\section{References}

Amindoust, A., Ahmed, S., Saghafinia, A., \& Bahreininejad, A. (2012). Sustainable supplier selection: a ranking model based on fuzzy inference system. Applied soft computing, 12(6), 1668-1677. http://dx.doi.org/10.1016/j.asoc.2012.01.023

Asamoah, D., Annan, J., \& Nyarko, S. (2012). AHP approach for supplier evaluation and selection in a pharmaceutical manufacturing firm in Ghana. International Journal of Business and Management, 7(10), 49-62. http://dx.doi.org/10.5539/ijbm.v7n10p49

Awasthi, A., Chauhan, S.S., \& Goyal, S.K. (2010). A fuzzy multi criteria approach for evaluating environmental performance of suppliers. International journal of production economics, 126(2), 370-378. http://dx.doi.org/10.1016/j.ijpe.2010.04.029

Bai, C., \& Sarkis, J. (2009). Supplier selection and sustainability: a grey rough set evaluation. Working paper No. 2009-05.

Bhutia, P.W., \& Phipon, R. (2012). Application of AHP and TOPSIS method for supplier selection problem. IOSR Journal of Engineering, 2(10), 43-50. http://dx.doi.org/10.9790/3021-021034350

Bottani, E., \& Rizzi, A. (2008). An adapted multi-criteria approach to suppliers and products selection: An application oriented to lead-time reduction. International Journal of Production Economics, 111, 763-781. http://dx.doi.org/10.1016/j.ijpe.2007.03.012

Cebi, F., \& Bayraktar, D. (2003). An integrated approach for supplier selection. Logistics Information Management, 16(6), 395-400. http://dx.doi.org/10.1108/09576050310503376

Chang, C.T. (2007). Multi-choice goal programming. Omega, The International Journal of Management Science, 35, 389-396. http://dx.doi.org/10.1016/j.omega.2005.07.009

Chang, B., Chang, C.-W., \& Wu, C.-H. (2011). Fuzzy DEMATEL method for developing supplier selection criteria. Expert systems with applications: An international journal, 38(3), 1850-1858.

Chen, C.M. (2009). A fuzzy-based decision-support model for rebuy procurement. International Journal of Production Economics, 122, 714-724.

http://dx.doi.org/10.1016/j.ijpe.2009.06.037

Chiu, Y.J., Chen, H.C., Shyu, J.Z., \& Tzeng, G.H. (2006). Marketing strategy based on customer behavior for the LCD-TV. Int. J. Manage. Decision Making, 7(2-3), 143-165.

http://dx.doi.org/10.1504/IJMDM.2006.009140

Gharakhani, D. (2012). The evaluation of supplier selection criteria by fuzzy DEMATEL method. Journal of Basic Applied Sci. Res, 2(4), 3215-3224.

Hori, S., \& Shimizu, Y. (1999). Designing methods of human interface for supervisory control systems. Control Eng. Pract., 7(11), 1413-1419. http://dx.doi.org/10.1016/S0967-0661(99)00112-4 
Humphreys, P.K., Wong, Y.K., \& Chan, F.T.S., (2003). Integrating environmental criteria into the supplier selection process. Journal of Materials Processing Technology, 138(1-3), 349-356. http://dx.doi.org/10.1016/S0924-0136(03)00097-9

Hsu, C.-W., Kuo, T.- C., Chen S.- H., \& Hu, A.H. (2013). Using DEMATEL to develop a carbon management model of supplier selection in green supply chain management. International Journal of Prod. Econs. 56(1), 164-172.

Jadidi, O., Hong, T.S., Firouzi, F., Yusuff, R.M., \& Zulkifli, N. (2008). TOPSIS and fuzzy multi-objective model integration for supplier selection problem. Journal of Achievements in Materials and Manufacturing Engineering, 31(2), 762-769.

Keskin, G.A., Ihan, S., \& Ozkan, C. (2010). The fuzzy art algorithm: A categorization method for supplier evaluation and selection. Expert Systems with Application, 37, 1235-1240. http://dx.doi.org/10.1016/j.eswa.2009.06.004

Kheljani, J.G., Ghodsypour, S.H., \& O'Brien, C. (2009). Optimizing whole supply chain benefit versus buyer's benefit through supplier selection. International Journal of Production Economics, 121, 482-493. http://dx.doi.org/10.1016/j.ijpe.2007.04.009

Kumar, J., \& Roy, N. (2010). A hybrid method for vendor selection using neural network. International Journal of Computer Applications, 11(12), 35-40. http://dx.doi.org/10.5120/1631-2193

Kuo, R., Wang, Y., \& Tien, F. (2010). Integration of artificial neutral network and MADA methods for green supplier selection. Journal of Cleaner Production, 18(12), 1161-1170. http://dx.doi.org/10.1016/j.jclepro.2010.03.020

Lee, A.H.I., Kang, H.-Y., Hsu C.-F., \& Hung, H.-C. (2009). A green supplier selection model for high- tech industry", Expert systems with applications. 36, 7917-7927.

http://dx.doi.org/10.1016/j.eswa.2008.11.052

Lin, C.T., Chen, C.B., \& Ting, Y.-C. (2011). An ERP model for supplier selection in electronics industry. Expert Systems with Applications, 38, 1760-1765.

http://dx.doi.org/10.1016/j.eswa.2010.07.102

Liou, J.J.H., Tzeng, G.H., \& Chang, H.C. (2007). Airline safety measurement using a novel hybrid model. Journal of Air Transport Management, 13(4), 243-249.

http://dx.doi.org/10.1016/j.jairtraman.2007.04.008

Opricovic, S., Tzeng, G.H. (2003). Defuzzification within a multicriteria decision model. International Journal of Uncertainty, Fuzziness and Knowledge-based Systems, 11, 635-652. http://dx.doi.org/10.1142/S0218488503002387

Radke, A.M. (2008). Sourcing Unique Components in the Electro-Mechanical Engineering Industry from Chinese suppliers, 51.

Tamura, M., Nagata, H., \& Akazawa, K. (2002). Extraction and systems analysis of factors that prevent safety and security by structural model. 41st SICE Annual Conference, Osaka, Japan. 
Tseng, M.L., \& Chiu, A.S. (2010). Evaluating firm's green supply chain management in linguistic preferences. Journal of cleaner production, 18, 1-10.

Tzeng, G.H., Chiang, C.H., \& Li, C.W. (2007). Evaluating intertwined effects in e-learning programs: A novel hybrid mcdm model based on factor analysis and DEMATEL. Exp. Syst. Appl., 32(4), 1028-1044. http://dx.doi.org/10.1016/j.eswa.2006.02.004

Upadhyay, A. (2012). Sustainability: Overview and Concepts. International Journal of Innovations in Business, 4, 268-273.

Wang, G., Huang, S.H., \& Dismukes, J.P. (2004). Product-driven supply chain selection using integrated multi-criteria decision-making methodology, Int. J. Production Economics, 91, 1-15. http://dx.doi.org/10.1016/S0925-5273(03)00221-4

Wang, S.J., \& Hu, H.A. (2005). Application of rough set on supplier's determination. Paper presented at the third annual conference on uncertainty.

Wang, Y.M., \& Elhag, T.M.S. (2006). Fuzzy TOPSIS method based on alpha level sets with an application to bridge risk assessment. Expert Systems with Applications, 31, 309-319. http://dx.doi.org/10.1016/j.eswa.2005.09.040

Weber, C.A., Current, J.R. (1993). A multiobjective approach to vendor selection. European Journal of Operational Research, 68(2), 173-184. http://dx.doi.org/10.1016/0377-2217(93)90301-3

Wu, W.W., \& Lee, Y.T. (2007). Developing global managers' competencies using the fuzzy DEMATEL method. Expert Systems with Applications, 32(2), 499-507.

http://dx.doi.org/10.1016/j.eswa.2005.12.005

Wu, D.S., \& Olson, D.L. (2008). Supply chain risk, simulation, and vendor selection. International Journal of Production Economics, 114, 646-655.

http://dx.doi.org/10.1016/j.ijpe.2008.02.013

Yeh, W.C., \& Chuang, M.C. (2010). Using multi-objective genetic algorithm for partner selection in green supply chain problems. Expert System Application, 38, 4244-4253. http://dx.doi.org/10.1016/j.eswa.2010.09.091

Zhu, Q., Dou, Y., \& Sarkis, J. (2010). A portfolio-based analysis for green supplier management using the analytical network process. Supply chain management: An International Journal, 15, 306-319. http://dx.doi.org/10.1108/13598541011054670 


\section{Appendix A}

\section{Nomenclature:}

\begin{tabular}{|c|c|}
\hline CFCS & Converting Fuzzy data into Crisps Scores. \\
\hline DEMATEL & Decision Making Trial and Evaluation Laboratory Model. \\
\hline TOPSIS & Technique for Order Performance by Similarity to Ideal Solution. \\
\hline ROS & Rights of stakeholders \\
\hline WS & Worker's safety \\
\hline ID & Information disclosure \\
\hline RFP & Respect for policy \\
\hline WT & Worker's training \\
\hline GD & Green design \\
\hline EC & Environmental competencies \\
\hline EMS & Environmental management system \\
\hline PC & Pollution control \\
\hline OTD & On time delivery \\
\hline S\&R & Service and relationship \\
\hline OEM & Original equipment manufacturers \\
\hline$S_{i, j}$ & Sustainability sub- criterion where $i, j=1,2, \ldots, n$ \\
\hline$A_{i}$ & Alternative suppliers where $i=1,2, \ldots, m$ \\
\hline$B_{i j}$ & Mean score influence of a sub- criterion on other sub- criteria. \\
\hline$a_{i j}$ & $\begin{array}{l}\text { Mean score influence of each sub- criterion divided by the summation of its influence on other sub- } \\
\text { criteria. }\end{array}$ \\
\hline$R_{i j}$ & Element of the total- relation matrix \\
\hline$I$ & Identity matrix. \\
\hline W & Sum of rows on the total- relation matrix \\
\hline$H$ & Sum of columns on the total- relation matrix \\
\hline$W+H$ & Degree of central role \\
\hline$W-H$ & Degree of relation. \\
\hline$P_{i j}$ & Normalized evaluation index for the alternative suppliers \\
\hline$g_{i j}$ & Performance of each alternative with respect to each sub- criterion. \\
\hline$V_{i j}$ & Weighted normalized decision matrix \\
\hline$V_{j}^{+}$ & Positive ideal solution. \\
\hline$V_{j}^{-}$ & Negative ideal solution \\
\hline$I^{\prime}$ & Advantage criteria \\
\hline$I^{\prime \prime}$ & Cost criteria. \\
\hline$d_{i}^{+}$ & Positive separation measure \\
\hline$d_{i}^{-}$ & Negative separation measure \\
\hline$L_{i}$ & Relative closeness of the alternatives to the ideal solution \\
\hline
\end{tabular}

Journal of Industrial Engineering and Management, 2014 (www. jiem. org)

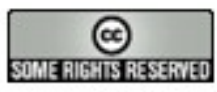

Article's contents are provided on a Attribution-Non Commercial 3. 0 Creative commons license. Readers are allowed to copy, distribute and communicate article's contents, provided the author's and Journal of Industrial Engineering and Management's names are included.

It must not be used for commercial purposes. To see the complete license contents, please visit http://creativecommons.

org/licenses/by-nc/3. $0 \%$. 